\title{
IAMJ
}

INTERNATIONAL

AYURVEDIC

MEDICAL JOURNAL

\section{EFFECTS OF VYAYAM AND NASYA IN THE MANAGEMENT OF HYPOTHYROIDISM: CONCEPTUAL REVIEW}

\author{
Shalu Jain ${ }^{1}$, Umesh Shukla ${ }^{2}$ \\ ${ }^{1}$ PG Scholar, ${ }^{2}$ Professor \& Head \\ PG Department of Panchakarma \\ Pt. Khushilal Sharma Government (Autonomous) Ayurveda College and Institute, Bhopal (MP), India
}

Corresponding Author: shalujainpiplia@gmail.com

\section{https://doi.org/10.46607/iamj1609062021}

(Published Online: June 2021)

Open Access

(C) International Ayurvedic Medical Journal, India 2021

Article Received: 28/05/2021 - Peer Reviewed: 09/06/2021 - Accepted for Publication: 10/06/2021

Check for updates

\begin{abstract}
Lifestyle is accountable for the origin of a diseases; it is a very ancient and famous theory in Ayurveda. Nowadays there has been a profound change in the dietary habits and lifestyle of human being due to modernization. Deleterious eating habits, along with sedentary lifestyle, cause various ailments including metabolic disorders. Thyroid gland is a key part of the human endocrine system and works together with nervous and immune system and it regulates metabolism by producing and secreting hormones into blood. Inadequate production of thyroid hormone is considered as hypothyroidism. Auto immunity plays a key role in the etiology of hypothyroidism. Global incidence of hypothyroidism is rising rapidly, and it is posing a major health challenge in both developing as well as developed world. Hypothyroidisms influence the standard of life of individuals, despite many progresses the modern management of hypothyroidism remains disappointing. Looking into the pathogenesis and complication of hypothyroidism, it requires a systemic and radical therapy for which ayurveda may provide a ray of hope through panchakarma, there is abnormality of Jatharagni and Dhatwagni, urdhvajatrugata sthan along with abnormality of Kapha and Vata Dosha as well as Kaphamedo-Avrita Vata. Thus, the line of treatment involves Deepana, Pachana, Srotoshodhana, Nasya, Vyayam and Kapha vata shaman.
\end{abstract}

Keywords: Hypothyroidism, Agnimandya, Metabolism, Nasya, Vyayam. 


\section{INTRODUCTION}

Manner of living is accountable for the origin of a diseases; it is a very famous theory in Ayurveda. Nowadays, there has been an extreme change in the dietary habits and lifestyle of individuals due to modernization and influence of western culture. Unhealthy eating pattern, along with sedentary lifestyle, cause various diseases including metabolic disorders.

Thyroid gland is a key part of the human endocrine system and works together with nervous and immune system and it regulates metabolism by producing and secreting hormones into blood. ${ }^{[1]}$ Inadequate production of thyroid hormone is considered as hypothyroidism and which is characterized by signs and symptoms like slower metabolism rate, weight gain, hair fall, forgetfulness, sleepiness, fatigue, constipation, dry and cold skin, menstrual disturbance etc. ${ }^{[2]}$

It is the most common disorders of thyroid gland and commonly encountered problem in clinical practice. It is also the commonest endocrine disorder and is believed to be common health issue in India as it is worldwide. According to projection, from various studies on thyroid disorders, it has been estimated that about 42 million Population in India is suffering from thyroid disorders. ${ }^{3}$

Global incidence of hypothyroidism is rising rapidly, and it is posing a major health challenge in both developing as well as developed world. ${ }^{[4]}$ The prevalence of hypothyroidism is high affecting approximately one in 10 adults in population and subclinical hypothyroidism is about $11 \%$ and more prevalent among the females, with male to female ratio being
$1: 6^{[5]}$. It is found to be $10.95 \%$ in adult urban population with significantly female number outweighing the males i.e. $15.86 \%$ in females and $5.02 \%$ in males. The prevalence of primary Hypothyroidism is high accounting for over $95 \%$ of total Hypothyroidism patients. Central Hypothyroidism of pituitary origin, occurrence rate is even lower i.e. 1 from 1000 cases ${ }^{[6]}$ Hypothyroidisms influence the standard of life of individuals, in spite of many progresses the modern management of hypothyroidism remains upsetting. The only treatment available is synthetic thyroid hormone which patient has to take lifelong and has certain side effects causes muscle cramp, weakness, restlessness, cardiac arrhythmia, palpitation, tachycardia, osteoporosis etc. ${ }^{[7]}$

\section{DISEASE REVIEW}

In Ayurveda classics there is no direct citation about how to understand the pathogenesis of hypothyroidism but ayurveda helps us to understand this path physiological phenomenon and the clinical manifestation. Certain pathogenic phenomenon that includes kaphavarit-vata ${ }^{[8]}$ kapha-medo-avrita vata ${ }^{[9]}$ galgand ${ }^{[10]}$ in urdhvjatrugat rogas, dhatvagnimandhya janya vikrati ${ }^{[11]}$ appear to have lead role in disease manifestation.

Vriddha Kapha by obstructing the channels vitiates the Vata Dosha also and Jatharagni gets impaired due to this Vriddha Kapha which leads to dhatwagnimandhya. This dhatwagnimandhya plays an important role in pathogenesis of hypothyroidism

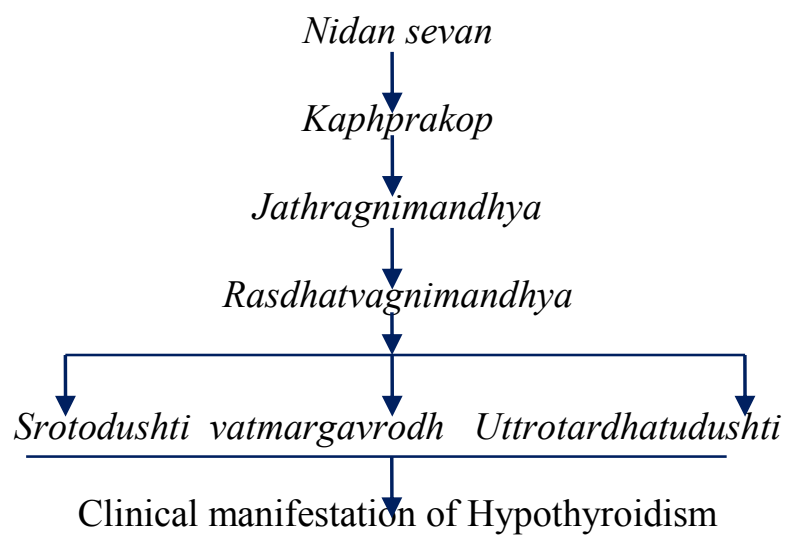




\section{MANAGEMENT}

Niragni swedana (Vyayam) and nasya are capable of carrying out all sorts of actions by virtue of the specific type and drugs are utilized in it and effectively encounter the pathogenesis of hypothyroidism. Niragni Swedan is indicated in kaph-medaavrita vata. ${ }^{[12]}$ Niragni swedan is performed in the form of Vyayam. ${ }^{[13]}$ Vyayam does kindling of agni and increases basal metabolic rate. Thyroid gland is situated in supraclavicular region (urdhvajatrugata sthan), which is a kaphsthan. Nasya is considered as the most specific procedure for disease of head and neck region. As in Ayurveda nose is considered as the door of head, hence nose is the suitable route for drug administration in urdhvajatugata ${ }^{[14]}$ rogas. This procedure helps us to achieve desired therapeutic outcomes.

\begin{tabular}{|l|l|l|l|l|}
\hline Procedure & Duration & Drug & DOSE & TIME \\
\hline Nasya & $\begin{array}{l}\text { 1-21 Days } \\
\text { (7 Days + 1day Rest +7 Days } \\
\text { + 1day Rest +5days Nasya) }\end{array}$ & Katutumbi tail & 6 drops in each nostril & Purvahn kal \\
\hline Niragni swedan & 1-21 Days & Vyayam & $\begin{array}{l}\text { Till Balardh vyayam } \\
\text { lakshan appear }\end{array}$ & - \\
\hline
\end{tabular}

\section{MATERIALAND METHODS:}

Literary resources like classical textbooks of Ayurveda, clinical trials, published manuscripts and clinical experience of treating cases.

1. Nasya :- Nose is the portal (gateway) of head ${ }^{[15]}$ The drug administered through nose as Nasya dravya reaches to the brain and eradicates only the morbid Doshas accountable for causing the disease. ${ }^{[16]}$ Thyroid gland is situated in supraclavicular region (urdhvajatrugata sthan.) As in Ayurveda nose is considered as the door of head, hence nose is the appropriate route for drug administration in urdhvajatugata rogas.

Nasya is the method of introducing medicine through the nose for either pacifying or rinsing or strengthening the supraclavicular region. ${ }^{[17]}$ The disease Hypothyroidism is Kapha dominent; hence the drugs which are having Kaphashamaka properties such as Ushna, Teekshna guna should be used in curing the disease. Katutumbi taila have Ushna, teekshna and Kaphashamaka properties. Thyroid gland is situated in urdhwajatrugata, which is a kaphasthana, hence the management of Hypothyroidism by katutumbi tail Nasya may be a better choice. Nasya has a direct influence on the functioning of thyroid gland.

2. Niragni swedan (Vyayam):- Niragni Swedan is advised in kaph-meda-avrita vata. ${ }^{[18] ~ N i r a g n i}$ swedan is performed in the form of Vyayam. [19]
Vyayam does kindling of agni and increases basal metabolic rate.

Vyayam gives about feeling of lightness of the body, increases ability to act, stability, capacity for all sorts of sorrow and mitigation of three doshas. ${ }^{[20]}$ Regular vyayam slow down the process of ageing, assist body to shape up, improve muscle strength, augments power of digestion and maintain health, removes laziness and produce tolerance towards tiredness, thirst, fatigue, heat and cold. [21] Vyayam does kindling of agni and increases metabolic activity which helps to digest the morbid doshas and mala, cleans the srotas and removes margavrodh. Vyayam is not only lightness of the body but also it gets rid of all imperfections and accretion of the digestive fire. Vyayam upgrades energy level and provides oxygen and nutrients to whole body assisting it to work more effectively. Vyayam plays an essential role in maintaining and stimulating the function of thyroid gland.

\section{DISCUSSION}

Hypothyroidism is kapha dominant; hence the drugs which are having kaphashamk properties should be utilized in curing the disease. With the help of previous pharmacological research ${ }^{[22]}$, we got that all the herbs evaluated here act on hypothalamus and pitui- 
tary gland directly or indirectly and stimulate the thyroid gland by nasya therapy. Hypothyroidism is known as lifestyle or stress or metabolic or autoimmune disorder. Vyayam (Physical activity) can indirectly improve subjective well-being. Vyayam plays an unambiguous role in the prevention and treatment of mental and physical health problem.

\section{CONCLUSION}

Hypothyroidism is major endocrine problem in present era. Katutumbi tail is more efficient in counteracting the pathogenesis of hypothyroidism at different levels. Nasya is a good measure for treat hypothyroidism. Vyayam is more effective in metabolic and stress disorder.

\section{REFERENCES}

1. https://healthywa.wa.gov.au/Articles/S_T/Thethyroid-gland

2. Ujjaliya Nitin-A comperative clinical evaluation of thyromax powder against thyroxin sodium in the management of hypothyroidism -2013 V.P.S.V. Ayurveda college, kottakal, Kerala

3. http://www.japi.org/thyroid_special_jan__ issue_2011/article_01.html assess on 12-9-15

4. Unnikrishnan A, Bantwal GijonM, et.al. Prevalence of hypothyroidism in adult: an epidemiological study in eight cities of India

5. Fatourechi, V.Subclinical Hypothyroidism: An Update for Primary Care Physicians' 'Mayo Clinic Proceedings, (2009), 84 (1): 65- 71.doi:10.4065/84.1.65. PMC 2664572.PMID 19121255

6. ..http;//www.endocrineweb.com/professional/hypoth yroidism/American-tyhroid- association-American thyroid Association guideline on the treatment of hypothyroidism

7. Shastri Kashinath, Chaturvedi Gorakhnath edited Charak Samhita of Agnivesha, revised by Charaka and Dridhbala,part II, Chaukhambha Bharati Academy,Varanasi.Reprint.,2009;

Chikitsha Sthana28/187; page no;808.

8. Shastri Kashinath, Chaturvedi Gorakhnath edited Charak Samhita of Agnivesha, revised by Charaka and Dridhbala, part II, Chaukhambha Bharati Academy, Varanasi.Reprint.,2009; Chikitsha Sthana28/224; page no; 814.

9. Shastri Kashinath, Chaturvedi Gorakhnath edited
Charak Samhita of Agnivesha, revised by Charaka and Dridhbala, part II, Chaukhambha Bharati Academy, Varanasi.Reprint.,2009; Chikitsha Sthana28/187; page no; 808 .

10. Sushruta, Sushruta Samhita, Ayurved-TattvaSandipika Commentary of ShriKaviraja Shastri Ambika Dutta, Chaukhamba Sanskrit Sansthan, Varanasi, reprint-2010, Nidan Sthan-11-chapter, verse23, page number 355

11. Sushruta, Sushruta Samhita, Ayurved-TattvaSandipika Commentary of ShriKaviraja Shastri Ambika Dutta, Chaukhamba Sanskrit Sansthan, Varanasi, reprint-2010, Chikitsa Sthan-32-chapter, verse-15, page number 175

12. Sushruta, Sushruta Samhita, Ayurved-TattvaSandipika Commentary of ShriKaviraja Shastri AmbikaDutta, Chaukhamba Sanskrit Sansthan, Varanasi, reprint-2010, Chikitsa Sthan-24-chapter, verse-39, page number 134

13. Sushruta, Sushruta Samhita, Ayurved-TattvaSandipika Commentary of ShriKaviraja Shastri AmbikaDutta, Chaukhamba Sanskrit Sansthan, Varanasi, reprint-2010, Chikitsa Sthan-24-chapter, verse-39, page number 134

14. Shastri Kashinath, Chaturvedi Gorakhnath edited Charak Samhita of Agnivesha, revised by Charaka and Dridhbala, part II, Chaukhambha Bharati Academy, Varanasi.Reprint.,2009; siddhi Sthana 2/22; page no;986

15. Agnivesha, Charaka Samhita, edited by Harish Kushwaha Chaukhamba Orientalia Prakashana, Varanasi,2011. Siddhisthana, 2/22. p.973.

16. Astangahrdayam, edited by Dr.Brahmanand Tripathi, Chaukhamba Sanskrit Pratishthan Prakashana, Delhi, 2009 Sutrasthana 20/1; p.246.

17. Digvesbhoye clinical study on trimada as adjuvant in the management of uncontrolled hypothroidism 2018 government akhandanand ayurved college, ahmedabad gujarat ayurved university

18. Sushruta, SushrutaSamhita, Ayurved-TattvaSandipika Commentary of ShriKaviraja Shastri Ambika Dutta, Chaukhamba Sanskrit Sansthan, Varanasi, reprint-2010, Chikitsa Sthan-24-chapter, verse-39, page number 134

19. Shastri Kashinath, Chaturvedi Gorakhnath edited Charak Samhita of Agnivesha, revised by Charaka and Dridhbala, part II, Chaukhambha Bharati Academy, Varanasi.Reprint.,2009; siddhi Sthana 2/22; page no;986 
20. Brahmanand Tripathi, Ganga Sahay Pandey, editor, Charak Samhita, Charak Chandrika Hindi commentary, Chaukhamba Surbharti Prakashan, 2007.p.175.

21. Ambikadutta Shastri, editor, Sushruta Samhita, Chaukhamba Sanskrit Sansthan, Varanasi, 2007.p.107.

22. Nidhi Nimeshwari et al / Int. J. Res. Ayurveda Pharm. 10 (4), 2019

\section{Source of Support: Nil}

\section{Conflict of Interest: None Declared}

How to cite this URL: Shalu Jain \& Umesh Shukla: Effects Of Vyayam And Nasya In The Management Of Hypothyroidism: Conceptual Review. International Ayurvedic Medical Journal \{online\} 2021 \{cited June, 2021\} Available from:

http://www.iamj.in/posts/images/upload/1249_1253.pdf 